\title{
Spatial distribution and egg production in squat lobsters (Decapoda: Munididae, Munidopsidae) from the collection of the Museu de Zoologia of the Universidade de São Paulo, Brazil
}

\author{
Patricio Hernáez ${ }^{1,2}$
}

\begin{abstract}
1. Universidad de Tarapacá - UTA, Facultad de Ciencias, Centro de Estudios Marinos y Limnológicos, Av. General Velásquez, 1775, Arica, Chile. (pahernaez@gmail.com)

2. Universidade Estadual Paulista - UNESP, Instituto de Biociências - IB, Grupo de Pesquisa em Biologia de Crustáceos - CRUSTA Câmpus do Litoral Paulista - CIP Praça Infante Dom Henrique, s/nº, Parque Bitaru, CEP $11330-900$, São Vicente, SP, Brazil.
\end{abstract}

\begin{abstract}
Spatial distribution and egg production of squat lobsters is examined from specimens deposited in the collection of the Museu de Zoologia of the Universidade de São Paulo (MZUSP), Brazil. A total of 1,346 specimens of squat lobsters were analyzed, out of which 169 were ovigerous females. Ovigerous females contained ten species of Munididae $(n=165)$ and three of Munidopsidae $(n=4)$. Eleven of the thirteen studied species were distributed along the Brazilian coast, while two of the remaining species in other marine regions. The analysis of bathymetric distribution revealed the presence of four species on the continental shelf ( $<200 \mathrm{~m}$ depth: M. spinifrons, M. pusilla, M. irrasa, M. flinti), two on the first layer of the continental slope (200-500 m: Munida forceps, A. longipes) and five distributed between 500 and 1,048 m (M. erinacea, M. constricta, M. valida, M. microphthalma, M. transtridens). Overall, species belonging to Munididae produced a higher number of eggs (554 \pm 619 eggs) but of minor size $(0.48 \pm 0.120 \mathrm{~mm})$ than species of Munidopsidae ( $13 \pm 10$ eggs; $1.12 \pm 0.337 \mathrm{~mm}$, respectively). Such tendency is consistent with the phylogeny of both clades whose common origin is reflected in morphological similarities both in larval and adult forms, but not in terms of the reproductive strategy that clearly separates the species belonging to these families. Results also demonstrated that egg size in squat lobsters is strongly associated with depth, which suggests the strong influence of habitat on the duration of larval development of these species.
\end{abstract}

KEYWORDS. Fecundity, egg size, Crustacea, South Western Atlantic.

RESUMEN. Distribución espacial y producción de huevos en langostillas (Decapoda: Munididae, Munidopsidae) de la colección del Museu de Zoologia de la Universidade de São Paulo, Brasil. Se examinó la distribución espacial y la producción de huevos de langostillas depositados en la colección del Museu de Zoologia de la Universidade de São Paulo (MZUSP), Brasil. Para ello, se analizaron 1.346 ejemplares, de los cuales 169 correspondieron a hembras ovígeras. Las hembras ovígeras estuvieron distribuidas en diez especies de Munididae y tres de Munidopsidae. Once de las trece especies estudiadas se distribuyeron en la costa brasilera, mientras que dos en otras regiones marinas. El análisis de la distribución batimétrica reveló la presencia de cuatro especies de langostillas sobre la plataforma continental (<200 m: M. spinifrons, M. pusilla, M. irrasa, M. flinti), dos en la primera franja del talud continental (200-500 m: Munida forceps, A. longipes) y cinco distribuidas entre 500 y $1048 \mathrm{~m}$ de profundidad (M. erinacea, M. constricta, M. valida, M. microphthalma, M. transtridens). En general, las especies de Munididae produjeron una alta cantidad de huevos (554 \pm 619 huevos) de pequeño tamaño $(0,48 \pm 0,120 \mathrm{~mm})$ comparado con las especies de Munidopsidae (13 \pm 10 huevos; $1,12 \pm 0,337 \mathrm{~mm}$, respectivamente). Esta tendencia es consistente con la filogenia de ambos clados cuyo origen en común se refleja en similitudes morfológicas tanto en las formas larvales como en las adultas, pero no así en la estrategia reproductiva que claramente separa las especies pertenecientes a estas familias. Nuestros resultados también demuestran que el tamaño del huevo en langostillas está correlacionado con la profundidad, sugiriendo una estrecha relación entre el hábitat y la duración del desarrollo larval de estas especies.

PALABRAS-CLAVE. Fecundidad, tamaño del huevo, Crustacea, Atlántico Sur Occidental.

Squat lobster is the common name for anomuran crabs of the families Chirostylidae, Galatheidae, Kiwaidae, Munididae and Munidopsidae. Members of these clades are distributed in all marine habitats (VAN DOVER et al., 1985; BABA, 2005), representing an important component of marine food webs in coastal zones and deepwater environments (Boyd, 1967; KashKina \& KashKin, 1993; Hoyoux et al., 2009). In particular, Munididae and Munidopsidae comprise two of the most diverse clades within squat lobsters, with more than 350 and 266 species, respectively (AHYONG et al., 2010). Munidids typically occur at the outer margin of the continental shelf, while munidopsids usually occupy from slope to abyssal depths (BABA et al., 2008, and references therein). Representatives of Munididae can 
reach high densities on soft bottoms (WeHRTMANN et al., 2010), wherefore several of these species are considered as an important fishery resource in certain regions of America (e.g., Pleuroncodes planipes, Cervimunida johni, Munida gregaria; WeHRTMANN \& ACUÑa, 2011).

The considerable variability observed among munidids and munidopsids, in terms of fecundity and egg size indicate important differences in the reproductive strategy of these decapods. Such issue has been analyzed in detail in several important contributions on the reproductive biology of these species (e.g., WENNER, 1982; VAN DovER et al., 1985; HartNOll et al., 1992; TAPElla et al., 2002; HeRnÁEz \& WeHrTMANN, 2011; KILGOUR \& ShIRLEY, 2014). In general, female size explains very well the observed variability in the fecundity in species of Munididae and Munidopsidae; the correlation coefficient (r) reported for some species of these families (e.g. van Dover \& WiLliams, 1991; HARTNOLl $e t$ $a l .$, 1992; TAPElla et al., 2002; HernÁEZ \& WeHRTMANN, 2011; KILGOUR \& SHIRLEY, 2014) is within the range reported in other families of anomuran, caridean and brachyuran decapods (e.g., Hines, 1991; COREY \& ReID, 1991; REID \& Corey, 1991; Hernáez \& Palma, 2003). Also, these studies report that munidids usually produce large number of small eggs from which planktotrophic larvae are released, while munidopsids incubate few but large eggs which produce lecitotrophic larvae. In accordance to van Dover \& WILLIAMS (1991), the squat lobster larvae hatched from small eggs tend to have a greater number of larval phases than species with large eggs.

Oceanographic expeditions conducted along the southwestern Atlantic, have provided abundant material on squat lobsters for the Brazilian coast (e.g., H.S.M. Challenger [1872-76], Steamer Blake [1877-79], Oceanographic Ship Prof W. Besnard [1997-98]). From the specimens collected during these expeditions, a series of subsequent contributions identified sixteen species of Munididae and five of Munidopsidae for the coast of Brazil (TAVARES \& Campinho, 1998; De Melo-Filho, 2006; Tavares et al., 2008), distributed at depths ranging from 13 to $1220 \mathrm{~m}$ (De Melo-Filho \& De Melo, 1992; De Melo-Filho \& Coelho-Filho, 2004; de Melo-Filho, 2006). Whilst it is true that munidids and munidopsids are common species of the Brazilian coast, the information about the egg production of these species is totally absent for this region.

Consequently, the present study analyzes the spatial distribution of egg bearing females in ten species of Munididae and three of Munidopsidae, previously deposited in the collection of the Museu de Zoologia of the Universidade de São Paulo (MZUSP), Brazil. Similarly, I analyzed the egg production (number and egg size) of these species to test if this aspect follows the trend reported in literature for species of Munididae and Munidopsidae. The information reported herein will contribute to the knowledge on the reproductive biology of squat lobsters from the Brazilian coast, improving our understanding of reproductive strategies in these ecologically important marine decapods.

\section{MATERIALS AND METHODS}

Ovigerous females were obtained from the collection of the Museu de Zoologia of the Universidade de São Paulo (MZUSP), São Paulo, Brazil. This collection contains the largest holdings of squat lobsters of Brazil, including 138 lots of Munididae and Munidopsidae from the South Western Atlantic and other marine regions. All these lots were checked for the presence of brooding females. In parallel, the registers of the museum (MZUSP) were checked to find information about the spatial distribution (latitudinal and bathymetric distribution) of ovigerous females. This information was used to construct a general map of geographical distribution of squat lobsters, as well as represent the bathymetric distribution of ovigerous females.

In all ovigerous females carapace length (CL: from anterior to posterior carapace margins) was measured under a light stereomicroscope (Olympus ${ }^{\circledR}$ SZ 61) equipped with a calibrated ocular micrometer. Considering that transparency of the eggs (here the term 'eggs' is used for developing embryos) was seriously affected during preservation in alcohol, embryos carried by brooding females were classified into two categories: stage I, round shape with yolk uniformly distributed, no eye pigments visible; stage II, oval shape, with eyes well developed and widely visible. The number of eggs (NE) carried by each female was estimated by gently separating the eggs from female pleopods and then directly counting them under a stereomicroscope (Olympus ${ }^{\circledR}$ SZ 61). Alternatively, all lots were inspected carefully in search of eggs detached from the females. In those lots where females with eggs were not kept separately, the loose eggs were separated depending on development stage, counted, and total number of eggs was divided in accordance with the total number of brooding females with embryos in stage I and II (respectively) deposited in each lot. Lastly, a sample of twenty eggs was randomly obtained from each egg mass and each egg was measured (widest and longest axis for each of twenty embryos per female) under a microscope equipped with a calibrated ocular micrometer. Egg volume (EV) was estimated with the formula for the volume of an ellipsoid (TURner \& LaWrence, 1979), EV $=1 / 6\left(\mathrm{EL}^{*} \mathrm{EW} * 2 \pi\right)$, where $\mathrm{EL}=$ egg length and $\mathrm{EW}=$ egg width. Given the low number of brooding females registered in some species, the differences in terms of the body size (CL), egg number (EN), egg length (EL) and egg volume (EV) were examined pooling specimens into the families Munididae and Munidopsidae. Next, the average of each variable was compared by using a t-test or Mann-Whitney U-test depending on whether the variances between the compared datasets were homogenous. Alternatively, it was explored whether egg number/egg length of species of squat lobster was related to depth (D). For its purpose, relation between EN/EL $x \mathrm{D}$ was examined by the Spearman correlation test $(\mathrm{p}>0.05)$.

Considering the importance of pleopods (Plp 1-5) for the incubation of embryos in species of Decapoda, I registered which one of these structures was involved into 
the transport of eggs during the embriogenesis of each species. Alternatively, I also analyzed whether the amount of eggs attached to pleopods differed from each other. For this purpose, the number of eggs attached to each pleopod was separately counted. Next, the average of eggs among pleopods was compared by using a one-way analyses of variance (ANOVA; ZAR, 1999). This analysis was conducted in species with sample size above ten specimens of ovigerous females.

Only six of the thirteen analyzed species had sufficient sample sizes to warrant the statistical estimation of the sizespecific fecundity model (see Tab. I). In these cases, the egg number (independently of development stage) and female size were subjected to regression analyses using a power function or allometric model $\left(\mathrm{y}=\mathrm{a} \mathrm{X}^{\mathrm{b}}\right)$, and logarithmically transformed (i.e. $\log \mathrm{y}=\log \mathrm{a}+\mathrm{b}[\log \mathrm{X}]$, where $\mathrm{a}$ is the intercept and $\mathrm{b}$ is the slope) with previous outliers removal by Studentized residuals' method. According to Somers (1991), fecundity and body size represent two different dimensions (volumetric vs linear, respectively), therefore, the theoretical value of slope based on an allometric model of size-specific fecundity should approximate 3.0. Conversely, when slope-value differs from 3.0, it is assumed that there is a lack of a simple volumetric relationship. Considering the above information, $b$-value of the ENxCL relationships was tested by using independent Student's t-test (ZAR, 1999).

\section{RESULTS}

General aspects. A total of 1,346 specimens of squat lobsters were revised, of which 169 (12.6\%) were ovigerous females. Brooding females were distributed in ten species of Munididae and three of Munidopsidae (Tab. I). Two other species of Munididae (Munida iris, MZUSP 13206; M. victoria, MZUSP 12256) and one of Munidopsidae (Munidopsis polita, MZUSP 13252) were examined not finding females carrying eggs in all these cases.

Spatial distribution of ovigerous females. Ovigerous females of ten of the thirteen species of squat lobsters had information on geographical distribution available. Eight of these species were collected along the Brazilian coast, between states of Espírito Santo and Rio Grande do Sul (Fig. 1). Within this area, diversity, expressed as richness of species, diminished from five to two species toward higher latitudes. In waters of the states of Espírito Santo and Rio de Janeiro, for example, a total of five species of squat lobsters were registered, while from São Paulo to Rio Grande do Sul, the number of species did not exceed two species per state (Fig. 1). Other two species, Munidopsis chuni and Paramunida scabra were colected in Angolan waters and central western Pacific, respectively (Fig. 1). There was no information in MZUSP record on the presence of ovigerous females of squat lobsters to the north of the Espirito Santo State.

Brazilian species of squat lobsters showed a marked pattern of ovigerous females vertical distribution. For instance, in Munida spinifrons, Munida pusilla, Munida irrasa and Munida flinti, ovigerous females were vertically distributed in the continental shelf $(<200 \mathrm{~m}$ depth), whereas Munida forceps and Agononida longipes, were found inhabiting the first layer of the continental slope (200 - 500 $\mathrm{m}$ depth; Fig. 2). In Munidopsis erinacea, Munida constricta, Munida valida and Munida microphthalma, brooding females ranged to depths between 500 and $1000 \mathrm{~m}$ depth, whereas in Munidopsis transtridens the brooding female was found about $1000 \mathrm{~m}$ depth (Fig. 2). The only brooding female collected in $M$. chuni and $P$. scabra was captured at about 1000 and $205 \mathrm{~m}$ depth, respectively.

Egg production of squat lobsters. Ovigerous females from the family Munididae measured from 3.4 to $24.3 \mathrm{~mm}$ CL $(12.7 \pm 4.50 \mathrm{~mm})$ whereas in Munidopsidae from 10.6 to $12.5 \mathrm{~mm} \mathrm{CL}(12.1 \pm 1.13 \mathrm{~mm})$. The average $\mathrm{CL}$ of brooding females did not differ statistically between munidids and munidopsids (Mann-Whitney U-test: [variances were heterogeneous]; $U=341.0, p>0.05$ ). Overall, species of Munididae produced a higher number of eggs ( $554 \pm 619$ eggs) but of minor size $(0.48 \pm 0.120 \mathrm{~mm})$ than species of Munidopsidae $(13 \pm 10$ eggs and $1.12 \pm 0.337 \mathrm{~mm}$, respectively). Such observation was statistically confirmed comparing the average of egg number (Mann-Whitney U-test: [variances were heterogeneous]; $\mathrm{U}=647.0, \mathrm{p}<$ 0.001), egg length (Mann-Whitney U-test: [variances were heterogeneous]; $\mathrm{U}=2.0, \mathrm{p}<0.001$ ) and egg volume (MannWhitney U-test: [variances were heterogeneous]; $\mathrm{U}=0.0, \mathrm{p}$ $<0.001$ ) between Munididae and Munidopsidae.

Ovigerous females in $M$. forceps reached the largest average CL $(20.4 \pm 2.01 \mathrm{~mm})$ and produced more eggs (1042 \pm 913 eggs) than all squat lobster species that had a sufficient sample size to estimate an average. Munida pusilla recorded the smallest ovigerous female examined in the present study, which measured $3.4 \mathrm{~mm} \mathrm{CL}$ and produced 15 eggs. On the contrary, $M$. valida recorded the largest ovigerous female which measured $24.3 \mathrm{~mm} \mathrm{CL}$ and produced 90 eggs. Moreover, results showed a significant relationship between egg size of squat lobsters and depth (Spearman test: rho $=0.71, p<0.05)$, but not between number of eggs and depth (Spearman test: rho $=-0.26, p>0.05$ ). Summaries of sample size, carapace-length, egg number and egg length for munidids and munidopsids species are provided in table 1 .

A positive correlation was statistically confirmed between EN and CL in females of four of the six species of squat lobster species (Tab. II, Fig. 3). Female size explained between 38 and $84 \%$ of the observed variability in the fecundity of $A$. longipes, $M$. constricta, $M$. flinti and $M$. forceps (Fig. 3). On the contrary, body size did not explain the number of eggs produced by females in M. irrasa and $M$. microphthalma (Tab. II, Fig. 3). The statistic analysis of slope (b) showed the absence of a simple volumetric relationship between EN and CL in three of the four analyzed species (Tab. II). In these cases, the null hypothesis was rejected given that slope-value was significantly smaller or larger than the expected theoretical value $(\mathrm{b}=3)$. In $M$. irrasa and M. microphthalma, this statistical test was not conducted because the EN x CL relationship was not significant in both squat lobster species (Tab. II). 
Tab. I. Range and average of carapace length (CL), egg number (EN) and egg length (EL) in thirteen species of squat lobsters (Munididae and Munidopsidae) of the Museu de Zoologia of the Universidade de São Paulo (MZUSP), Brazil. Number of individuals (N), standard deviation (SD). Asterisk show species in which the relationship number of eggs and female size was fitted.

\begin{tabular}{|c|c|c|c|c|c|c|c|c|}
\hline \multirow[t]{2}{*}{ Taxa } & \multirow[t]{2}{*}{$\mathrm{N}$} & \multicolumn{2}{|c|}{ Carapace length $(\mathrm{mm})$} & \multicolumn{2}{|c|}{ Egg number } & \multicolumn{2}{|c|}{ Egg length (mm) } & \multirow{2}{*}{$\begin{array}{c}\text { No. Catalogue } \\
\text { (MZUSP) }\end{array}$} \\
\hline & & Range & Mean \pm SD & Range & Mean \pm SD & Range & Mean \pm SD & \\
\hline \multicolumn{9}{|l|}{ Munididae } \\
\hline Agononida longipes & $17 *$ & $10.7-17.3$ & $13.4 \pm 1.95$ & $137-2078$ & $733 \pm 643$ & $0.37-0.60$ & $0.49 \pm 0.060$ & $12839,12840,14436,15353$ \\
\hline Munida constricta & $44^{*}$ & $9.3-14.9$ & $12.0 \pm 1.48$ & $82-1380$ & $361 \pm 236$ & $0.27-0.69$ & $0.43 \pm 0.079$ & $16308,16310,16719,16725$ \\
\hline M. flinti & $31 *$ & $8.1-15.6$ & $11.5 \pm 1.77$ & $82-2440$ & $987 \pm 648$ & $0.28-0.61$ & $0.44 \pm 0.063$ & $\begin{array}{c}5141,5153,5156,5159,5160, \\
10303,10309,10312,10324, \\
10325,10326,10327,10329, \\
10331,10333,10335,10336, \\
10340,10355,10360,10362, \\
10367,10368,16570\end{array}$ \\
\hline M. forceps & $24 *$ & $15.5-24.1$ & $20.4 \pm 2.01$ & $80-3060$ & $1042 \pm 913$ & $0.60-0.91$ & $0.70 \pm 0.067$ & $\begin{array}{c}6515,10786,12374,12386 \\
13654,16385,21437,21438 \\
21439,21440,21441\end{array}$ \\
\hline M. irrasa & $24 *$ & $5.3-8.2$ & $7.1 \pm 0.82$ & $30-327$ & $129 \pm 66$ & $0.31-0.59$ & $0.40 \pm 0.062$ & $\begin{array}{c}5180,5188,5189,5208,10400 \\
10411,11076\end{array}$ \\
\hline M. microphthalma & $18^{*}$ & $11.7-19.6$ & $15.2 \pm 2.06$ & $45-787$ & $239 \pm 218$ & $0.46-0.69$ & $0.54 \pm 0.031$ & 16305,16313 \\
\hline M. pusilla & 03 & $3.4-4.6$ & $4.0 \pm 0.60$ & $15-35$ & $27 \pm 11$ & $0.31-0.33$ & $0.32 \pm 0.010$ & $13219,13483,18816$ \\
\hline M. spinifrons & 02 & $4.6-5.5$ & --- & $53-97$ & --- & $0.37-0.43$ & --- & 10754 \\
\hline M. valida & 01 & 24.3 & --- & 90 & --- & 0.39 & --- & 12797 \\
\hline $\begin{array}{l}\text { Paramunida scabra } \\
\text { Munidopsidae }\end{array}$ & 01 & 7.4 & --- & 430 & --- & 0.52 & --- & n.i. \\
\hline Munidopsis chuni & 01 & 13.3 & --- & 27 & --- & 0.88 & --- & n.i. \\
\hline M. erinacea & 02 & $10.6-12.5$ & --- & $8.0-12.0$ & --- & $0.89-1.10$ & --- & 9856 \\
\hline M. transtridens & 01 & 12.0 & --- & 4 & --- & 1.60 & --- & 18839 \\
\hline
\end{tabular}

Tab. II. Allometric regression equations logarithmically transformed for the estimation of egg production in six species of squat lobsters from the Brazilian coast. Coefficient of determination $\left(\mathrm{r}^{2}\right)$, sum of squares ( $\left.\mathrm{ss}\right)$, Fisher's exact value (f), probability value (p), and null hypothesis for slope test $(\mathrm{b}=3)$. EN= egg number, $\mathrm{CL}=$ carapace length. Asterisk denote a non-significant relationship $(\mathrm{p}>0.05)$ between egg number and body size.

\begin{tabular}{|c|c|c|c|c|c|c|c|}
\hline Species & $\mathrm{N}$ & $\log y=b(\log X)+\log a$ & $\mathrm{r}^{2}$ & ss & $\mathrm{f}$ & $\mathrm{p}$ & $\begin{array}{l}\text { t-test } \\
\mathrm{b}=3\end{array}$ \\
\hline Agononida longipes & 14 & $\mathrm{EN}=4.83 \times \mathrm{CL}-6.11$ & 0.84 & 7.59 & 70.63 & $<0.001$ & no \\
\hline Munida constricta & 33 & $\mathrm{EN}=1.68 \times \mathrm{CL}+1.56$ & 0.38 & 1.42 & 19.83 & $<0.001$ & no \\
\hline Munida flinti & 18 & $\mathrm{EN}=2.66 \times \mathrm{CL}+0.64$ & 0.68 & 2.80 & 35.61 & $<0.001$ & yes \\
\hline Munida forceps & 19 & $\mathrm{EN}=8.94 \times \mathrm{CL}-20.11$ & 0.66 & 13.84 & 35.66 & $<0.001$ & no \\
\hline Munida irrasa & 18 & $\mathrm{EN}=1.17 \times \mathrm{CL}+2.50$ & 0.17 & 0.32 & 3.53 & $>0.05^{*}$ & --- \\
\hline Munida microphthalma & 17 & $\mathrm{EN}=1.91 \times \mathrm{CL}-0.06$ & 0.09 & 1.12 & 1.54 & $>0.05 *$ & --- \\
\hline
\end{tabular}

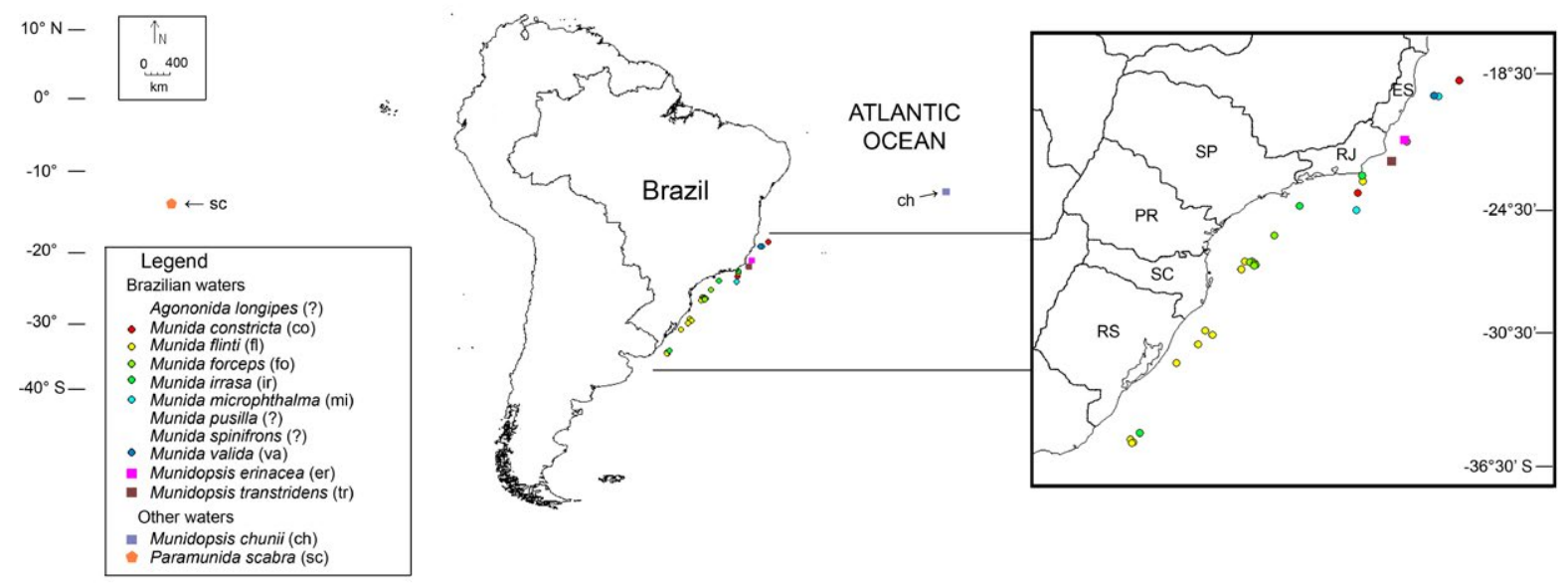

Fig. 1. Latitudinal distribution in squat lobsters (Munididae and Munidopsidae) along the Brazilian coast. Spatial distribution in Paramunida scabra from the Pacific Ocean waters is also shown. In legend box, symbol '?' indicates absence of information on specific spatial distribution in archives of the Museu de Zoologia of the Universidade de São Paulo (MZUSP), Brazil. ES, RJ, SP, PR, SC, RS, represent the Brazilian states of Espirito Santo, Rio de Janeiro, São Paulo, Paraná and Rio Grande do Sul, respectively. 


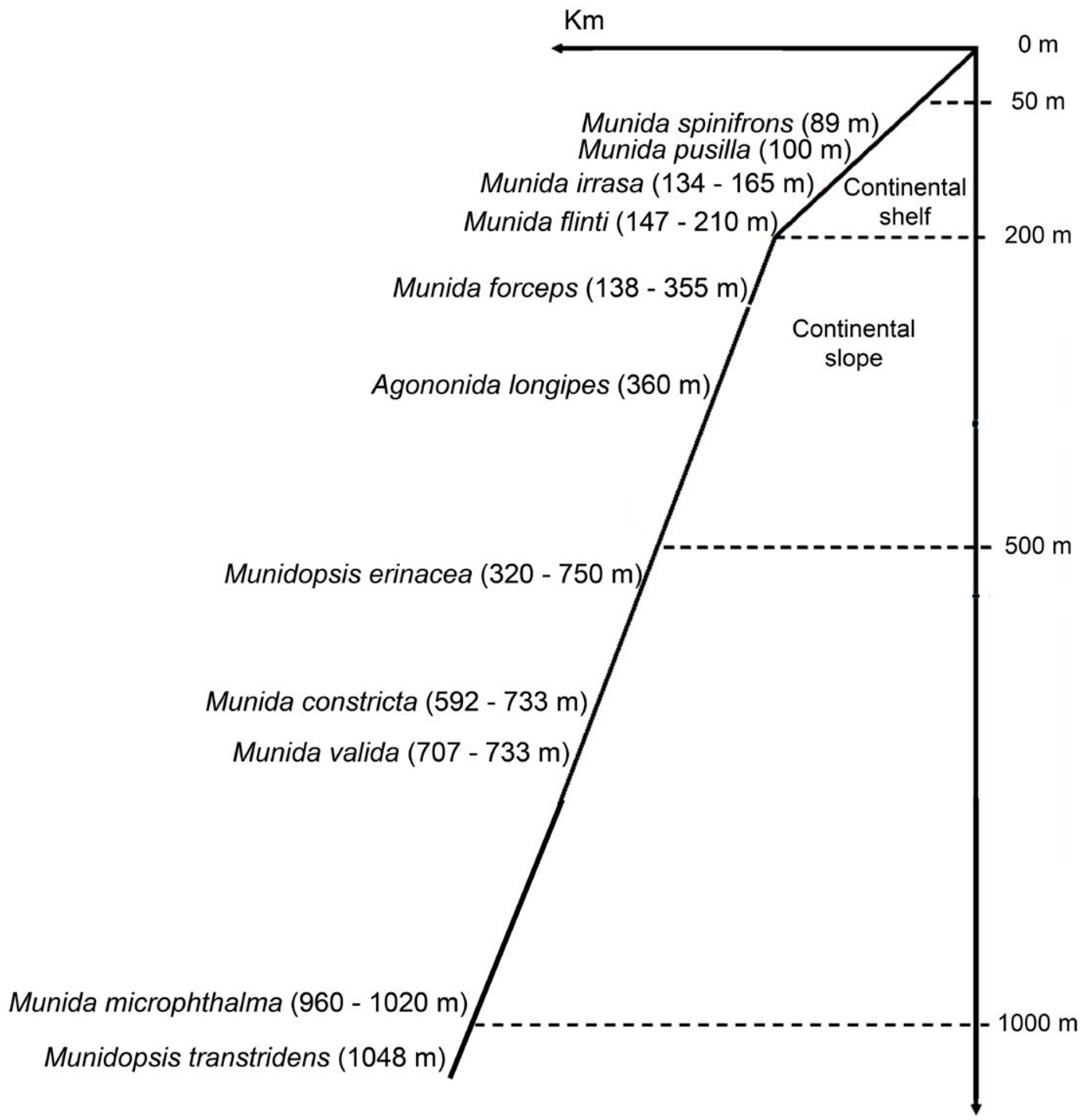

Fig. 2. Bathymetric distribution of ovigerous females in eleven squat lobster species (Munididae and Munidopsidae) from the Brazilian coast. Depth range for each species is shown within brackets.

In females of all analyzed species, the first pair of pleopods was absent. In A. longipes, $M$. flinti, $M$. forceps and $P$. scabra, females transported their eggs using the pleopods II-V, whereas using the pleopods III-V in the remaining species. In all analyzed species, the fourth pleopod transported the greater number of eggs compared to other pleopods (see species marked with asterisk in Tab. I). Only two species, A. longipes and M. forceps showed statistical differences among the total number of eggs attached to each pleopod (one-way ANOVA: A. longipes, $\mathrm{f}=9.38, \mathrm{p}<0.05$; M. forceps, $\mathrm{f}=15.60, \mathrm{p}<0.05)$.

\section{DISCUSSION}

The present study provided information about egg production for nine of the sixteen species of Munididae and for two of the five species of Munidopsidae reported along the Brazilian coast. Previous studies had provided data about spatial distribution of squat lobsters from Brazil (DE
Melo-Filho \& de Melo, 1992; Tavares \& Campinho, 1998; De Melo-Filho \& Coelho-Filho, 2004; de Melo-Filho, 2006; TAVARES et al., 2008) but this is the first report that showed, among other aspects, fecundity and egg size of these species. Whilst it is true that this information comes from specimens preserved in alcohol, in general, egg production in Decapoda has rarely been analyzed from living females (for an exception, see Wehrtmann \& Andrade, 1998). Another limitation of the present study was the small sample size observed in most of the analyzed species, which limited the realization of some statistical analyses and therefore the implications of the present study. However, most squat lobster habitats are difficult to access, which makes the obtaining of large sample sizes difficult (KILGOUR \& SHIRLEY, 2014). Specimens analyzed here were collected through scientific expeditions which used a rigorous sampling effort in bottom grounds between 100 and $1100 \mathrm{~m}$ depth. Therefore, outcomes reported in this study should be reliable in terms 


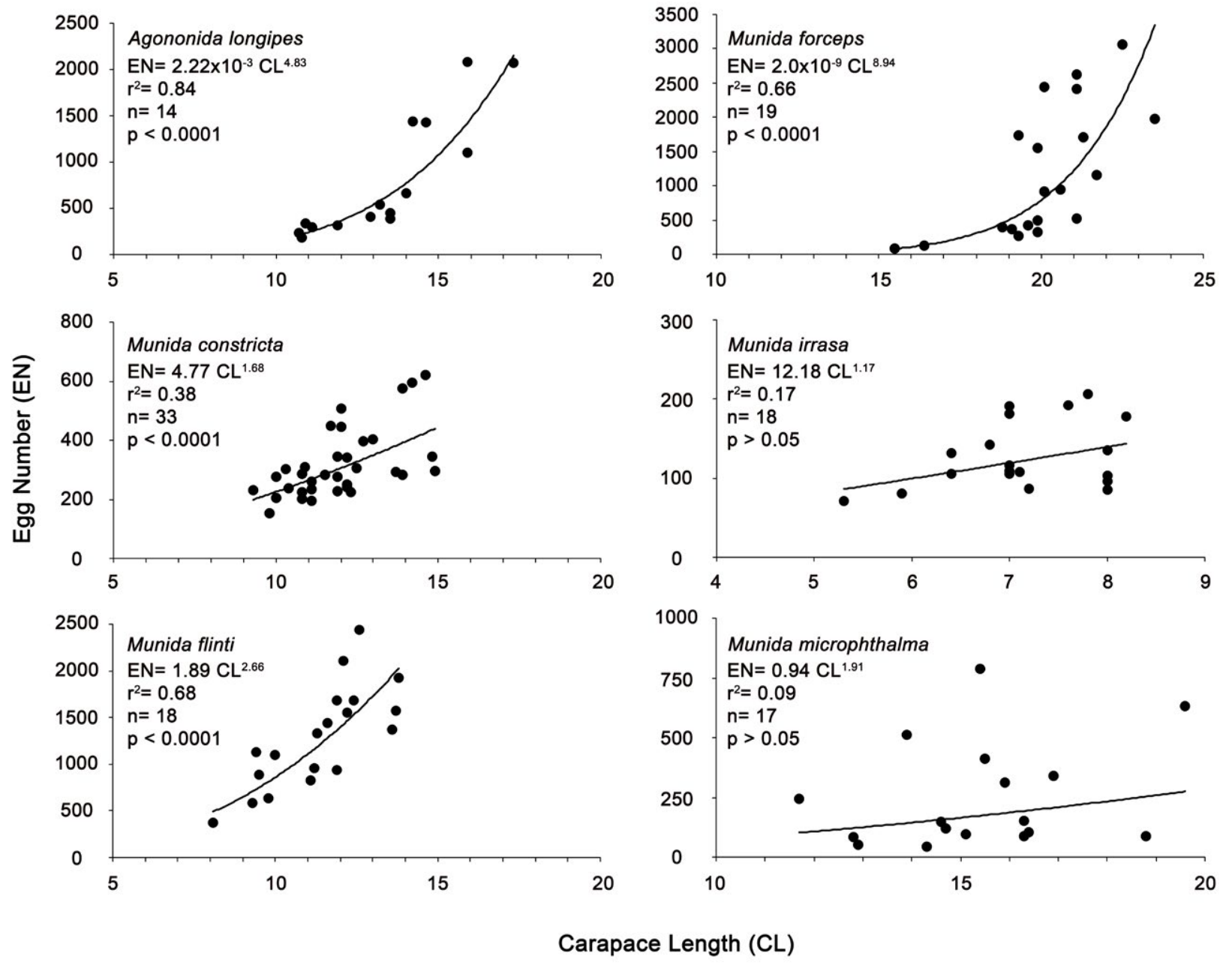

Fig. 3. Fecundity relationships involving number of eggs $(\mathrm{EN}) v s$. carapace length $(\mathrm{CL})$ in six squat lobsters of Munididae from the coast of Brazil.

of the sampling method with which ovigerous females were collected.

Temperature governs the spatial distribution and reproductive cycle of many marine invertebrates (SASTRY, 1983). In the deepwater squat lobster, Pleuroncodes monodon, ovigerous females are mainly concentrated in areas where the sea surface is cooled by upwelling events (Palma \& Arana, 1997; Hernáez \& Wehrtmann, 2014). According to these researchers, larvae of squat lobsters are released in areas of coastal upwelling because in these areas the food is abundant, thus warranting the larval survival. This information may explain why ovigerous females of most of the species analyzed $(\mathrm{N}=8)$ were concentrated in the Southeast region of the Brazilian coast where seasonal upwelling events (December to March) provoke the drop of sea surface temperature in around $10^{\circ} \mathrm{C}$ in relation to normal months in which it ranges between $25^{\circ} \mathrm{C}$ and $27^{\circ} \mathrm{C}$ (Rodrigues \& LORENZZETTI, 2001).

The number of eggs produced by females of squat lobsters allowed to separate them into two groups: (i) species carrying large numbers of small eggs (e.g., A. longipes, $M$. constricta, M. flinti, M.forceps, M. irrasa, M. microphthalma,
M. pusilla, M. spinifrons, M. valida, and P. scabra), and (ii) species carrying fewer and larger eggs (e.g. Munidopsis chunii, M. erinacea, M. transtridens). Such tendency was consistent with the phylogeny of both clades whose common origin is reflected in morphological similarities both in larval and adult forms (BABA et al., 2008; SCHNABEL et al., 2011), but not in terms of the reproductive strategy that clearly separated the species belonging to these families. Results also demonstrated that egg size in squat lobsters was strongly associated with depth, thus suggesting a close relation between habitat and the duration of larval development of these species; in terms of a significant reduction of larval phases with the depth or an increase of the lecitotrophy towards deepwater in these anomuran decapods (VAN DovER \& Williams, 1991). The life-history trade-off between a large number of small versus fewer and larger eggs has been repeatedly studied in an attempt to understand the evolution of planktotrophic and lecithotrophic larvae of marine invertebrates (McEDWARD, 1997).

The fecundity was positively correlated with the body size in four out of the six species of squat lobsters exceptions: M. irrasa and M. microphthalma (Fig. 3), a result 
also known for other squat lobsters (TAPELLA et al., 2002; Hernáez \& Wehrtmann, 2011; for various exceptions, see KILGOUR \& SHIRLEY, 2014). In cases of significant correlation between fecundity $(\mathrm{EN})$ and carapace length $(\mathrm{CL}), \mathrm{r}^{2}$ values were relatively lower $(17-72 \%$; Fig. 3$)$, compared with what has been reported for other munidids from the western Atlantic, whose determination coefficient ranged between 32 and $85 \%$ (e.g., Munida gregaria: TAPELLA et al., 2002; also see KILGOUR \& SHIRLEY, 2014). The observed variability in $r^{2}$ values suggests the influence of endo-exogenous factors that might provoke a significant loss of eggs during the embryogenesis (for review see KURIS, 1991). Another factor to consider is the long time of storage of ovigerous females which might have caused a significant loss of eggs during their maintenance in alcohol. Excepting $M$. forceps, the relationship between fecundity and CL was negative allometric in three species of Munida, which indicates a diminishing in egg production toward larger females (Tab. II). In squat lobsters, deviations from the theoretical value of 3.0 reported for models describing the size-specific fecundity may reflect (i) presence of discrete reproductive groups displaying separate size-specific fecundity (HERNÁEZ \& WEHRTMANN, 2011) or (ii) selective egg loss due to predators or parasites (GONZÁleZ \& ACUÑA, 2004). I did not detect the presence of parasites in the egg mass of species studied; therefore, I speculate that the observed low ' $b$ ' value may be associated with a concentration of egg production in a particular age/size group. This aspect needs further attention in future studies.

All studied species lacked the first pair of pleopods. Depending on species, embryos were attached from secondthird to fifth pair of pleopods. To best of my knowledge, pleopod fecundity is unknown for the majority of decapod crustaceans including squat lobsters. Eggs are expected to be equally distributed across the pleopods in order to avoid massive loss of embryos. Yet, the number of eggs increased from Plp2-Plp5, being the fourth pair the most important for egg carrying (34-44\% of total egg mass). This uneven distribution is probably due to constraints related to abdomen folding. More studies are necessary to ascertain whether there is a tendency among reptant decapods.

Acknowledgments. The author thanks CAPES-Brazil (20102012) and CONICYT-Chile (2012-2013) for his doctoral fellowship. I am also very grateful with Marcos Tavares, Curator of the Crustacea collection of the Museu de Zoologia, Universidade de São Paulo (MZUSP), Brazil, for facilitating the access to the biological material used in this study. I thank the anonymous reviewers for comments that improved the manuscript.

\section{REFERENCES}

Ahyong, S. T.; Baba, K.; Macpherson, E. \& Poore, G. C. B. 2010. A new classification of the Galatheoidea (Crustacea: Decapoda: Anomura). Zootaxa 2676:57-68.

BABA, K. 2005. Deep-sea chirostylid and galatheid crustaceans (Decapoda: Anomura) from the Indo-West Pacific, with a list of species. Galathea Reports 20:1-317.

Baba, K.; Macpherson, E.; Poore, G. C. B.; Ahyong, S. T.; Bermúdez, A.; Cabezas, P.; Lin, C. W.; Nizinzki, M.; Rodrigues, C. \& Schnabel, K. E. 2008. Catalogue of squat lobsters of the world (Crustacea: Decapoda: Anomura - families Chirostylidae, Galatheidae and Kiwaidae). Zootaxa 1905: $1-220$.
Boyd, C. M. 1967. The benthic and pelagic habitats of the red crabs, Pleuroncodes planipes. Pacific Science 21:394-410.

Corey, S. \& ReID, D. M. 1991. Comparative fecundity of decapod crustaceans. I. The fecundity of thirty tree species of nine families of caridean shrimps. Crustaceana 60:270-294.

De Melo-Filho, G. A. S. 2006. Reports on the results of the N.Oc. 'Prof. W. Besnard' expeditions to the southern coast of Brazil under the Revizee Program: Chirostylidae and Galatheidae (Crustacea: Decapoda: Anomura). Zootaxa 1238:1-22.

De Melo-Filho, G. A. S. \& De Melo, G. A. S. 1992. Designation of lectotypes for the species of Munida (Crustacea: Anomura: Galatheidae) collected by the U.S. Coast Survey Steamer Blake (1877-1879) and the description of a new species. Proceedings of the Biological Society of Washington 105:512-520.

De Melo-Filho, G. A. S. \& Coelho-Filho, P. A. 2004. Material of Munida Leach (Decapoda: Galatheidae) collected off the northeast coast of Brazil under the Revizee Program. Nauplius 12:59-64.

GonZÁLEZ, M. T. \& ACUÑA, E. 2004. Infestation by Pseudione humboldtensis (Bopyridae) in the squat lobsters Cervimunida johni and Pleuroncodes monodon (Galatheidae) off northern Chile. Journal of Crustacean Biology 24:618-624.

Hartnoll, R. G.; Rice, L. \& AtTrill, M. J. 1992. Aspects of the biology of the galatheid genus Munida (Crustacea, Decapoda) from the porcupine Seabight, Northeast Atlantic. Sarsia 76:231-246.

Hernáez, P. \& Palma, S. 2003. Fecundity, egg volume and reproductive output of five species of intertidal porcellanids from northern Chile (Decapoda, Porcellanidae). Investigaciones Marinas 31:35-46.

Hernáez, P. \& Wehrtmann, I. S. 2011. Sexual maturity and egg production in an unexploited population of the red squat lobster Pleuroncodes monodon (Decapoda, Galatheidae) from Central America. Fisheries Research 107:276-282.

Hernáez, P. \& Wehrtmann, I. S. 2014. Breeding cycle of the red squat lobster Pleuroncodes monodon H. Milne Edwards, 1837 (Decapoda, Muninidae) from deepwater Pacific of Costa Rica. Marine Ecology 35:204-211.

Hines, A. H. 1991. Fecundity and reproductive output in nine species of cancer crabs (Crustacea, Brachyura, Cancridae). Canadian Journal of Fisheries and Aquatic Sciences 48:267-275.

Hoyoux, C.; Zbinden, M.; Samadi, S.; Gaill, F. \& Compere, P. 2009. Wood-based diet and gut microflora of a galatheid crab associated with Pacific deep-sea wood falls. Marine Biology 156:2421-2429.

KashKinA, A. A. \& Kashkin, N. I. 1993. The Mexican red crab Pleuroncodes planipes Stimpson 1860 (Galatheidae) as an intermediate trophic link in the upwelling ecosystem off California Peninsula. Okeanologiya 33:579-586.

Kilgour, M. J. \& Shirley, T. C. 2014. Reproductive biology of galatheoid and chirostyloid (Crustacea: Decapoda) squat lobsters from the Gulf of Mexico. Zootaxa 3754:381-419.

KuRIS, A. 1991. A review of patterns and causes of crustacean brood mortality. In: WENNER, A. \& KURIS, A. eds. Crustacean egg production: variations in life history patterns. Crustacean Issues 7. Rotterdam, Balkema, p. 117-141.

MCEDWARD, L. R. 1997. Reproductive strategies of marine benthic invertebrates revisited: facultative feeding by planktotrophic larvae. The American Naturalist 150:48-72.

Palma S. \& Arana, P. 1997. Aspectos reproductivos del langostino colorado (Pleuroncodes monodon H. Milne Edwards, 1837), Chile frente a la costa de Concepcion. Investigaciones Marinas 25:203-221.

ReID, D. M. \& CoRey, S. 1991. Comparative fecundity of decapod crustaceans. II. The fecundity of fifteen species of anomuran and brachyuran crabs. Crustaceana 61:175-189.

Rodrigues, R. R. \& Lorenzzetti, J. A. 2001. A numerical study of the effects of bottom topography and coastline geometry on the Southeast Brazilian coastal upwelling. Continental Shelf Research 21:371-394.

SASTrY, A. N. 1983. Ecological aspects of reproduction. In: VernBerG, F. J. \& Vernberg, W. B. eds. The Biology of Crustacea. Vol. 8. New York, Academic Press. p. 179-270p.

Schnabel, K. E.; Ahyong, S. T. \& MaAs, E. W. 2011. Galatheoidea are not monophyletic - Molecular and morphological phylogeny of the squat lobsters (Decapoda: Anomura) with recognition of a new superfamily. Molecular Phylogenetics and Evolution 58:157-168. 
SOMERs, K. M. 1991. Characterizing size-specific fecundity in crustaceans. In: Wenner, A. \& Kuris, A. eds. Crustacean egg production: population and fisheries aspects. Crustacean Issues 7. Rotterdam, Balkema, p. 357-378.

Tapella, F.; Lovrich, G. A.; Romero, M. C. \& Thatje, S. 2002. Reproductive biology of the crab Munida subrugosa (Decapoda: Anomura: Galatheidae) in the Beagle Channel, Argentina. Journal of the Marine Biological Association of the United Kingdom 82:589595.

TAVAres, M. \& CAmpinho, P. 1998. Three new records of deep-sea squat lobsters of the genus Munidopsis Witheaves from the southwestern Atlantic Ocean (Decapoda: Galatheidae). Crustacean Research 27:88-100

Tavares, M.; De Melo-Filho, G. A. S. \& de Melo, G. A. S. 2008. The deepsea squat lobster Munidopsis transtridens Pequegnat and Pequegnat, 1971 (Decapoda: Anomura: Galatheidae) from the Southwestern Atlantic. Nauplius 16:95-99.

Turner, R. L. \& Lawrence, J. M. 1979. Volume and composition of echinoderm eggs: implications for the use of egg size in life history models. In: STANCIK, S. E. ed. Reproductive ecology of marine invertebrates. Marine Science 9. Columbia, University South Carolina Press, The Belle W. Baruch Library, p. 25-40. van Dover, C. L. \& Williams, A. B. 1991. Egg size in squat lobsters (Galatheoidea): constraint and freedom. In: Wenner, A. \& KURIS, A. eds. Crustacean egg production: variations in life history patterns. Crustacean Issues 7. Rotterdam, Balkema, p. 143-156.

van Dover, C. L.; Factor, J. R.; Williams, A. B. \& Berg, C. J. 1985. Reproductive patterns of decapod crustaceans from hydrothermal vents. In: Jones, M. L. ed. Hydrothermal vents of the eastern Pacific: an overview. Bulletin of the Biological Society of Washington 6:223-227.

Wehrtmann, I. S. \& Acuña, E. 2011. Squat lobster fisheries. In: Poore, G. C. B.; Ahyong, S. T. \& TAYlor, J. eds. The Biology of Squat Lobsters. Melbourne and Boca Raton, CRC Press, CSIRO Publishing, p. 297-322.

Wehrtmann, I. S. \& Andrade, G. 1998. Egg production in Heterocarpus reed $i$ from northern Chile, with a comparison between iced and living females (Decapoda: Caridea: Pandalidae). Ophelia 49:71-82.

Wehrtmann, I. S.; Herrera-Correal, J.; Vargas, R. \& Hernáez, P. 2010. Squat lobsters (Decapoda: Anomura: Galatheidae) from deepwater Pacific Costa Rica: species diversity, spatial and bathymetric distribution. Nauplius 18:69-77.

WENNER, E. L. 1982. Notes on the distribution and biology of Galatheidae and Chirostylidae (Decapoda: Anomura) from the Middle Atlantic Bight. Journal of Crustacean Biology 2:360-377.

ZAR, J. H. 1999. Biostatistical Analysis. Upper Saddle River, Prentice Hall. 663p. 